\title{
A New Concept of Composite Material for High Speed Boats
}

\author{
ADRIAN CARAMATESCU, COSTEL IULIAN MOCANU*, ALINA MODIGA \\ Dunarea de Jos University of Galati, 47 Domneasca Str., 800008, Galati, Romania
}

\begin{abstract}
The body of a craft is subjected to a series of complex loads, both static and dynamic. The global strength of such a body is given by the entire assembly of the hull, deck and strengthening framing system, all of these components working together [1]. Such a boat must first of all fulfill a very important requirement, namely: minimum hull resistance so that the engine power would primarily be used to achieve the highest possible speed. This can only be achieved if the hull wetted surface is as small as possible, which leads to the need to reduce the hull asembly weight. Thus, in this paper there are proposed and tested a number of nine lamination alternatives for the initial structure, designed as a sandwich system with different types of core materials. From the total nine alternatives, three of them are hybrid structures in which there are explored structural alternatives with several types of core materials. The verification of structures obtained with the proposed materials and lamination schedules was made using numerical methods both for naval hydrodynamics to determine loads and for naval structures for global body strength and analysis.
\end{abstract}

Keywords: composite hull, sandwich composites, high speed boat, experimental validation, full scale experiment, numerical modelling, FEA, planing boat

In order to validate the calculation methodology, a series of experimental tests were carried out on the Laguna 565 boat model made by Plasma Company in Galaj, Romania. The trials were conducted on the Danube River at various speeds (up to $12 \mathrm{~m} / \mathrm{s}$ ) and navigation conditions. The experimental model was equipped with resistive strain gauges before completion (marked M1 to M10) so that variations of the normal stresses can be tracked at the measuring points. An accelerometer, a tilt and speed transducers were also installed to validate the loads used for the numerical hydrodynamic model. These measured values were compared with the results of the numerical analysis, considering the material first formulated on the craft numerical model as isotropic material (recommended by the classification rules) using the FEMAP finite element analysis software. The same numerical analysis was also performed considering the composite as orthotropic material, using a FEMAP specialized module for laminate materials.

The dimensioning of the shell and framing elements of a boat is usually made in accordance with a classification society. In this case, DNV-GL I-3-3 Classification Rules [2] applicable to boats and yachts up to 24 meters in length were used by the builder, company PLASMA Galati. The scantling provides a calculation methodology which results in the mass of the reinforcement material required for each part of the shell and framing elements. An approximate computing solution for the thickness of the final layers is also provided, assuming a ratio of $30 \%$ reinforcement material and $70 \%$ resin in the laminated volume, which is the usual ratio for open molds hand lay-up lamination. The craft instrumentation is depicted in figure 1.

In the construction of high-speed crafts the coice material used is sigle skin Glass Reinforced Polyester (GRP). This has many advantages in comparison with the traditional materials (steel and aluminium), one of the major ones being its low density compared to metals; however, the latest trends demand high-speed crafts to be as light-weight as possible. Within the current study, calculations and measurements were made in order to find a material with mechanical characteristics comparable with those of the single skin GRP, but with reduced body mass.

A common definition of the composite material applied to GRP describes the glass fibers as the reinforcement and unsaturated polyester resin as the matrix; the fiber glass does not chemically interact with the resin. Figure $2 a$ presents two flat laminae together with their main directions of the reinforcements. In the construction of boat hulls, laminated monolithic layers are usually used. The hull shell (wall thickness) of the boat is represented by a stack of laminae binded together, having different orientations of the main directions (fig. 2b). Laminates are

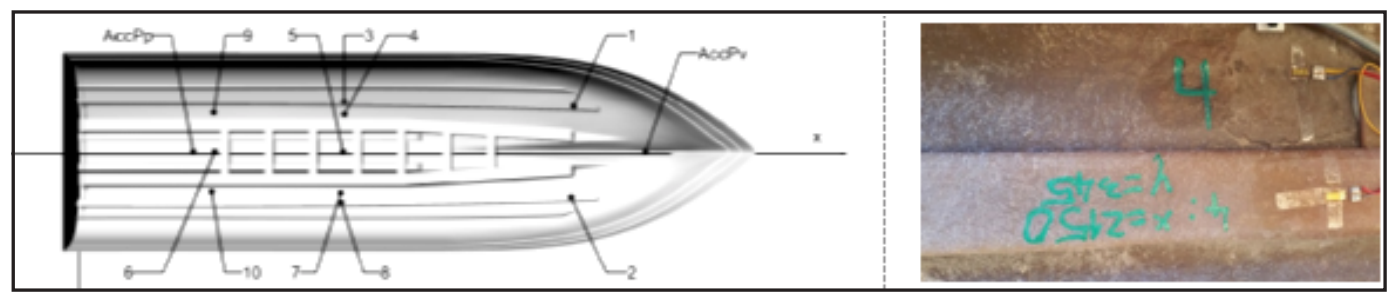

Fig. 1. Location schematics of the measuring devices (110 strain gauges, AccPv and AccPp are accelerometers). The inclinometer has been located at the same point as the AccPp

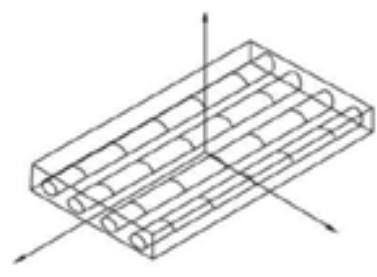

a

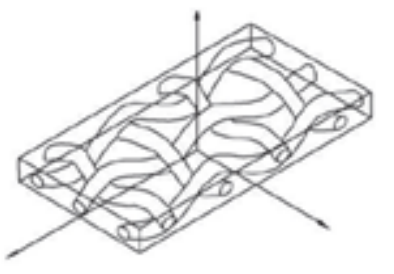

\footnotetext{
* email: costel.mocanu@ugal.ro
}

$\bullet 56 \bullet$ No. 1 \2019

http://www.revmaterialeplastice.ro 
layers made of different materials, having relative constant thickness made in resin reinforced with fibers [3]. Because of this stacking topology on layers, GRP may not be considered to be in full an isotropic material.

For accurately determining the characteristics of the material used in the construction of the craft, a section of $500 \mathrm{~mm}$ in length, located amidship has been laminated, using the exact same conditions used in the construction of the experimental hull (fig. 3a). The aim of the lamination of this piece was to take a series of samples from different areas of the shell (keel, bottom, sideboard) in order to test them in the laboratory, using the Instron 8002 test machine from Dunarea de J os University of Galati. From this sample a total of 11 test specimens of sized $20 \times 300 \mathrm{~mm}^{2}$ were extracted.

The values in table 1 show the mechanical characteristics obtained following the mechanical tests while their graphical variations provided by the traction test machine are shown in figure $3 b$.

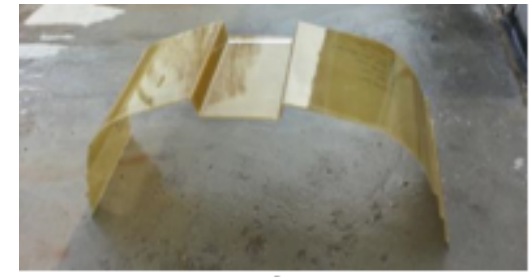

a)

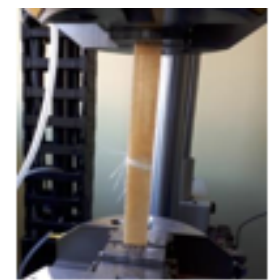

b)
Fig. 3 The test sample used for test specimens with the Instron 8002 test machine

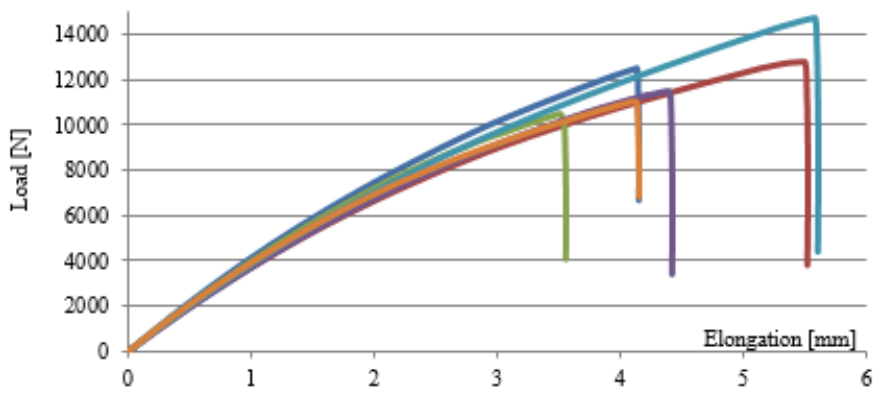

Fig. 4. Elongation/load chart for the $5 \mathrm{~mm}$ thick specimen set

The lamination schedule for each part of the hull is presented in table 2 below. Abbreviations used are: CSM Chopped Strand Mat - a random even distribution of short filaments - 100 to $120 \mathrm{~mm}$ of glass fiber, WR - Woven Roving - a woven cloth with $90^{\circ}$ between webs. The value following the abbreviation is the weight of the reinforcement, expresses in $\mathrm{g} / \mathrm{m}^{2}$.

It is obvious that the laminate weight per area unit is decreasing as the number of laminae is reduced. The highest loads are applied on the bottom, and the stress decreases on the sides. The amount of reinforcement is imposed by the rules of classification companies, while the resin is proportional with the volume of the reinforcement.

The characteristics of a reinforcement material used in combination with the resin can be obtained from the mechanical characteristics of each material in part using the volumetric ratio. This approach is highly practical because the obtained characteristics may be adjusted according to the volumetric ratio specific to each laminating workshop and especially according to the method used to obtain the laminate (manual lamination, vacuum, simultaneous projection, etc). The volumetric ratio is very easy to be monitored with simple elements and without special training for the technicians.

$$
\begin{gathered}
E_{L i}=E_{f i} V_{f}+E_{m i} V_{m} \\
\frac{1}{E_{T i}}=\frac{V_{f}}{E_{f i}}+\frac{V_{m}}{E_{m i}} \\
\frac{1}{G_{L T i}}=\frac{V_{f}}{G_{f i}}+\frac{V_{m}}{G_{m i}} \\
v_{L T}=v_{f} V_{f}+v_{m} V_{m},
\end{gathered}
$$

where:

$-E_{1}$ is the planar elasticity modulus of the lamina on the direction $i$

$-E_{f}$ is the planar elasticity modulus of the reinforcement on the direction $i$;

$-E_{m i}$ is the planar elasticity modulus of the matrix on the direction $i$;

$-E_{T}$ is the bending elasticity modulus;

$-G_{T T}$ is the shear planar modulus of the lamina;

$-G_{f}$ the shear modulus of the reinforcement;

$-G_{m}$ is the shear modulus of the matrix;

$-v_{\text {LT }}$ is the Poisson coefficient of the lamine;

$-v_{f}{ }_{f T}$ is the Poisson coefficient of the reinforcement;

$-v_{m}$ is the Poisson coefficient of the matrix;

$-V_{f}^{m}$ is the volumetric ratio of the reinforcement;

$-\mathrm{V}_{\mathrm{m}}^{\mathrm{f}}$ is the volumetric ratio of the matrix.

In table 3 the mechanical characteristics of the reinforcement layers used in the manufacturing of the

\begin{tabular}{|c|c|c|c|c|c|}
\hline $\begin{array}{c}\text { Test } \\
\text { specimen }\end{array}$ & $\begin{array}{c}\text { Thickness } \\
{[\mathbf{m m}]}\end{array}$ & $\begin{array}{c}\text { Width } \\
{[\mathbf{m m}]}\end{array}$ & $\begin{array}{c}\text { Tensile yeld strength } \\
{[\mathbf{M P a}]}\end{array}$ & $\begin{array}{c}\text { Elongation at break } \\
{[\mathbf{m m}]}\end{array}$ & $\begin{array}{c}\text { Young's modulus } \\
{\left[\mathbf{M} \mathbf{P a}_{\mathbf{a}} \mathbf{x} \mathbf{1 0} \mathbf{0}^{\mathbf{3}}\right.}\end{array}$ \\
\hline $\mathbf{1}$ & 4,9 & 19,98 & 127,79 & 4,129 & 8,67 \\
\hline $\mathbf{2}$ & 5 & 19,78 & 127,75 & 5,496 & 7,406 \\
\hline $\mathbf{3}$ & 4,9 & 20 & 116,58 & 3,511 & 9,134 \\
\hline $\mathbf{4}$ & 5,1 & 20,05 & 133,22 & 4,387 & 8,718 \\
\hline $\mathbf{5}$ & 5 & 19,87 & 165,44 & 5,579 & 8,628 \\
\hline $\mathbf{6}$ & 4,98 & 19,88 & 115,49 & 4,111 & 8,407 \\
\hline \multicolumn{7}{|c|}{ Mean Value } & 131,04 & 4,53 & 8,494 \\
\hline \multicolumn{3}{|c|}{ Minimum value } & 165,44 & 5,579 & 9,134 \\
\hline \multicolumn{3}{|c|}{ Standard deviation } & 115,491 & 3,511 & 7,406 \\
\hline
\end{tabular}

Table 1

MECHANICAL CHARACTERISTICS OF THE LAMINATE USED IN THE CONSTRUCTION OF THE INITIAL STRUCTURE (GRP)

\begin{tabular}{|c|c|c|c|c|}
\hline Laminate topology & Keel & Bottom side & Sideboards & Deck \\
\hline $\mathbf{l}$ & CSM 450 & CSM 450 & CSM 450 & CSM 450 \\
\hline $\mathbf{2}$ & CSM 450 & CSM 450 & CSM 450 & CSM 600 \\
\hline $\mathbf{3}$ & CSM 450 & WR 300 & CSM 450 & WR 300 \\
\hline $\mathbf{4}$ & WR 300 & CSM 450 & WR 300 & CSM 450 \\
\hline $\mathbf{5}$ & CSM 450 & WR 500 & CSM 450 & \\
\hline $\mathbf{6}$ & WR 500 & CSM 450 & & \\
\hline $\mathbf{7}$ & CSM 450 & & & \\
\hline $\mathbf{8}$ & CSM 450 & & 2100 & 1800 \\
\hline Total weight $\left[\mathbf{g}^{\mathbf{2}}\right]$ & 3500 & 2600 & 4.90 & 4.20 \\
\hline
\end{tabular}

Table 2

DESCRIPTION OF THE LAMINATION ON EACH TYPE OF SHELL ELEMENT 


\begin{tabular}{|c|c|c|c|c|}
\hline Mechanical properties & CSM 450 & CSM 600 & WR 300 & WR 500 \\
\hline Ex [MPa] & 7800 & 8500 & 10000 & 14000 \\
\hline$E y[M P a]$ & 7800 & 8500 & 10000 & 14000 \\
\hline $\boldsymbol{G}[\mathbf{M P a}]$ & 3000 & 3270 & 4954 & 6936 \\
\hline $\boldsymbol{V}$ & 0,3 & 0,3 & 0,0092 & 0,0092 \\
\hline $\boldsymbol{\rho}\left[\mathrm{g} / \mathrm{mm}^{3}\right]$ & $2,10 \mathrm{E}-03$ & $2,10 \mathrm{E}-03$ & $1,90 \mathrm{E}-03$ & $1,90 \mathrm{E}-03$ \\
\hline
\end{tabular}

\begin{tabular}{|c|c|c|}
\hline 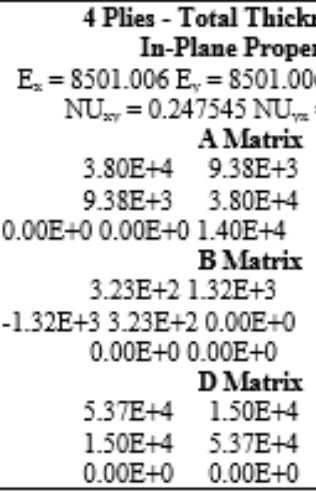 & $\begin{array}{l}\text { aess }=4.2 \\
\text { rties } \\
6 \mathrm{G}_{2 y}=3347.91 \\
=0.247545 \\
0.00 \mathrm{E}+0 \\
0.00 \mathrm{E}+0 \\
0.00 \mathrm{E}+0 \\
6.40 \mathrm{E}+2 \\
0.00 \mathrm{E}+0 \\
0.00 \mathrm{E}+0 \\
1.92 \mathrm{E}+4\end{array}$ & 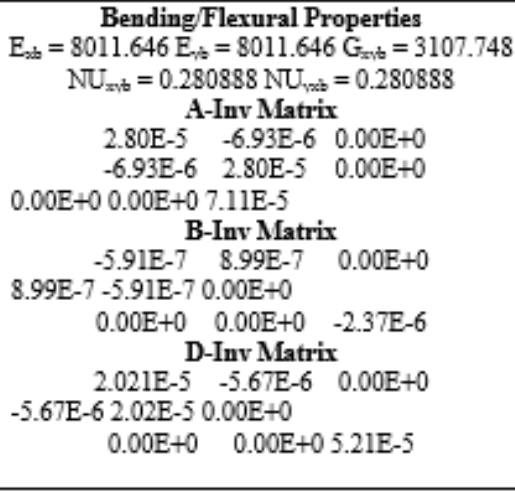 \\
\hline
\end{tabular}

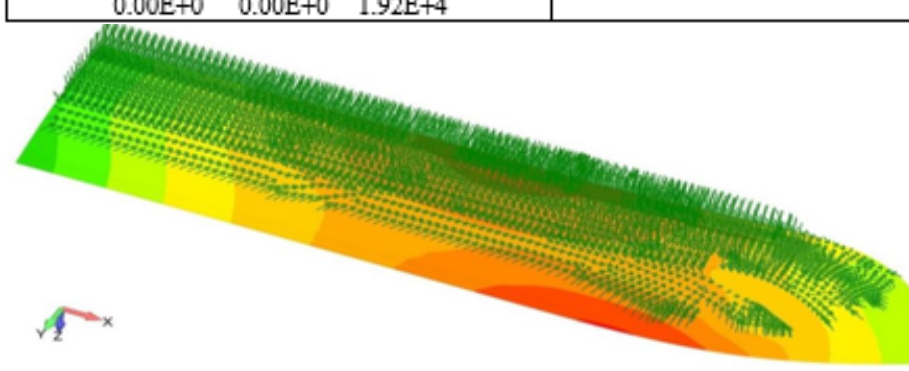

laminate under analysis are presented, in the impregnated state.

A very interesting aspect of the FEMAP calculation module used is that once the laminae are defined and the stacking sequence is set, the mechanical properties of the laminate are automatically calculated. This calculation is exemplified in table 4 for the laminate corresponding to the deck, resulting in mechanical properties almost identical to those obtained in the test laboratory.

The boat loads were obtained using a Computational Fluid Dynamic (CFD) simulation in the NUMECA software $[1,6]$. The pressure variations were extracted from the pressure field and defined as a $6^{\text {th }}$ order polynomial distribution function, on a series of $100 \mathrm{~mm}$ width strips defined alongside the hull, then applied onto the numerical FEA hull [1] (fig. 5).

The results of the experimental and numerical analysis were compared in order to evaluate the methodology proposed. Due to large amount of data output, in this paper it will be presented just the $10 \mathrm{~m} / \mathrm{s}$ case, in table 5 . Similar results have been obtained for all the other speed cases studied.

As it can be seen from the table, the errors resulted considering the GRP as isotropic material in the FEA simulations is consistent. A reasonable error threshold
Table 3

MECHANICAL PROPERTIES FOR COMPOSITE LAYERS OF REINFORCEMENT $[4,5]$

Table 4

CALCULATION OF MECHANICAL PROPERTIES PERFORMED IN FEMAP, EXEMPLIFIED FOR DECK LAMINATION SCHEDULE
Fig. 5. Extreme pressure loads, planning regime at 10 $\mathrm{m} / \mathrm{s},[1]$ Table 5

accepted by the register classification companies and in general engineering is under $10 \%$. The comparative analysis of the stresses between the experimental data and the numerical simulations indicates that the orthotropic model characterizes better the natural phenomena.

It can be concluded that the presented methodology is also applicable to evaluate the new material concepts proposed to replace classical GRP in the high-speed craft construction.

The next step was to use this validated methodology to evaluate different combinations of reinforcements and core materials. For a coherent analysis of the results, the stress and displacements, variations will be tracked at the same points where strain gauges were installed.

Multiple optimization of composites is a wide field of research [7] The current literature focuses on the sandwich structures with an increased interest because of the multiple combinations between classical composite faces working with lightweight core materials [8-10]. The boatbuilding sector uses core materials ever since its widespread development, therefore this material is a common choice when it comes to stiffening a panel. However, until recently most applications were using balsa core, an organic material with outstanding reduced density; however, due to frequent water ingression into the core, that becomes rotten and the two faces are no longer part

THE COMPARATIVE VALUES OF STRESS, NUMERICAL AND EXPERIMENTAL DATA [1]

\begin{tabular}{|c|c|c|c|c|c|c|}
\hline \multirow{3}{*}{ Strain gauge } & \multicolumn{6}{|c|}{ Speed $10[\mathrm{~m} / \mathrm{s}]$, Normal Stress $[\mathrm{MPa}]$} \\
\hline & \multicolumn{3}{|c|}{ Material formulation } & \multicolumn{3}{|c|}{ Deviations [\%] } \\
\hline & 1. Isotropic & 2. Orhtotropic & 3. Experiment & $1-2$ & $1-3$ & $2-3$ \\
\hline $\mathbf{M}$ & -0.0469 & -0.04198 & -0.0368 & 11.72 & 27.45 & 14.08 \\
\hline $\mathrm{M} 2$ & -0.0453 & -0.04052 & -0.0371 & 11.80 & 22.10 & 9.22 \\
\hline $\mathbf{M B}$ & -0.1564 & -0.13992 & -0.1249 & 11.78 & 25.22 & 12.03 \\
\hline M4 & -0.9789 & -0.87536 & -0.8594 & 11.83 & 13.91 & 1.86 \\
\hline M5 & -0.5346 & -0.4782 & -0.4272 & 11.79 & 25.14 & 11.94 \\
\hline M6 & -0.0231 & -0.02068 & -0.0182 & 11.70 & 26.92 & 13.63 \\
\hline M7 & -0.9643 & -0.86235 & -0.8587 & 11.82 & 12.30 & 0.43 \\
\hline MB & -0.1575 & -0.14092 & -0.1241 & 11.77 & 26.91 & 13.55 \\
\hline $\mathrm{MO}$ & -0.0413 & -0.03701 & -0.0351 & 11.59 & 17.66 & 5.44 \\
\hline M10 & -0.0383 & -0.03433 & -0.0291 & 11.56 & 31.62 & 17.97 \\
\hline & & & Mean error & 11.7 & 22.9 & 10.0 \\
\hline
\end{tabular}




\begin{tabular}{|c|c|c|c|c|}
\hline Mechanical properties & Coremat & PVC Foam & Coremat & PVC Foam \\
\hline & \multicolumn{2}{|c|}{$[\mathrm{MPa}]$} & \multicolumn{2}{|c|}{ Testing standard } \\
\hline Bending strength & 8,5 & 1,4 & ASTM D 790 & DNN 53423 \\
\hline Transversal modulus of elasticity & 1250 & 40 & ASTM D 790 & ISO 1209 \\
\hline Traction strength & 4 & 1,3 & ASTM C297 & DNN 53571 \\
\hline $\begin{array}{l}\text { Compression strength, } 10 \% \\
\text { deformation }\end{array}$ & 10 & 58 & ISO 844 & DNN 53421 \\
\hline Shear Strength & 3 & 0,8 & ASTM C273-61 & ASTM C273-61 \\
\hline Shear modulus & 25 & 22 & ASTM C 273-62 & ASTM C393 \\
\hline
\end{tabular}

Table 6

THE MECHANICAL PROPERTIES OF THE CORE MATERIALS $[11,12]$ ot the same structure. This study will consider two sinthetic materials as cores, due to their water resistance and therefore extended usage.

One of the materials used in the composition of sandwich is Coremat. This is the commercial name of a type of core material that is supplied by the company Lantor. This material is made from non-woven polyester fibers, compatible with any type of resin used in procedures for hand lay-up of GRP in open or vacuumed moulds. It has a series of equidistant perforations designed to reduce the shear in the layers adjacent to the core. It is available in thicknesses between 2 and $10 \mathrm{~mm}$, having the mechanical properties described in table 7 and the appearance shown in figure 6 . In this study, it was used the $3 \mathrm{~mm}$ thick version with a density of $540 \mathrm{~kg} / \mathrm{m}^{3}$ in the resin impregnated state.

The second type of core material used is a PVC foam, partially precut, having a glass-fiber fabric of negligible thickness on the uncut side, which is only meant to keep together the foam cassettes. The trade name of the material is M-55-SCRIM, is produced by the Crystex Company and has a thickness of $10 \mathrm{~mm}$ and a density of $60 \mathrm{~kg} / \mathrm{m}^{3}$. The mechanical properties of the material are given in table 6 while the appearance can be seen in figure 7.

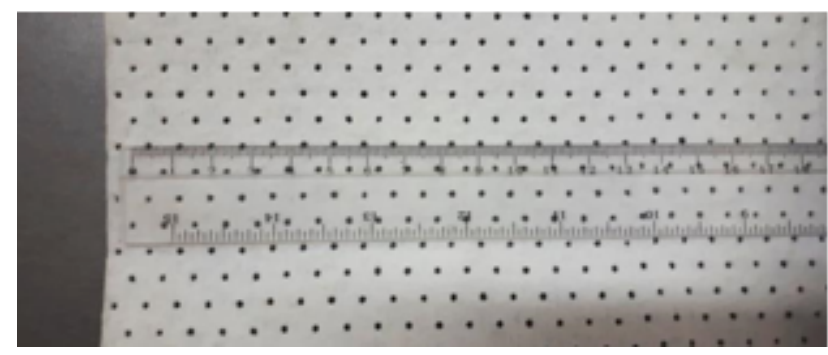

Fig. 6. Appearance of a layer of Coremat with a thickness of $3 \mathrm{~mm}$

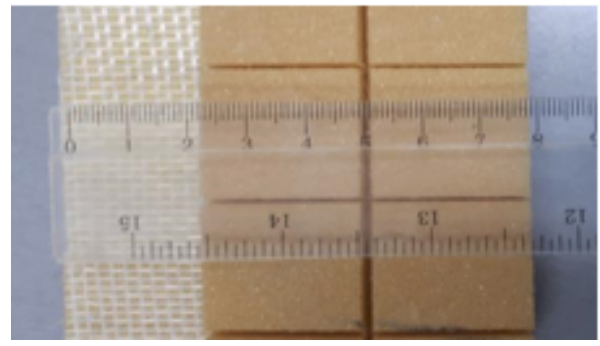

Fig. 7. Appearance of a layer of core foam M-55-SCRIM with thickness of $10 \mathrm{~mm}$
During navigation, a watercraft can be subjected to extreme loading conditions, which can result partial ot total loss of structural integrity; therefore the rules imposed by the classification companies primarily take into account these extreme loading conditions and require sprecific calcullations to be performed in order to demnstrate the integrity of the hull tremains intact even under these extreme loads. Therefore, the comparative analysis that was conducted took into account failure criteria of the laminates. In the case of conventional materials, the failure criteria are relatively simple and easy to put into practice, based on the material's strength parameters. In the case of composite materials, the analysis of failure criteria is more complex since they are constitued of at least two distinct phases. When multiaxially overstressing the composite anisotropic materials, their nature and direction of the overstressors may lead to a state of complex stress, which requires the need to adopt specific conditions which combine the parameters of the statuses of stress with the limit parameters of the material to assess the time at which the composite material fails.

In order to be able to mathematically characterize the failure of a composite, the phenomenon will need to be characterised from the point of view of the excitation parameters and the response that it generates. From a micromecanic point of view, it can be said that the failure is installed at the moment in which there is a discontinuity of the response received from the excited object. The discontinuities of technical interest which may be encountered are the occurrence of non-linearity in the tension-deformation relation, the occurrence of an irreversible deformation or the termination of the bidirectional correspondence of the tension-deformation function due to rupture.

Mechanical excitation may result from stress, deformation or mechanical work. In the absence of other external factors (chemical, thermal or other), a failure criteria can be characterized by the following expressions:

$$
\begin{gathered}
\mathrm{f}\left(\sigma_{\mathrm{ij}}, A\right)=0 \\
\mathrm{~g}\left(\varepsilon_{\mathrm{ij}}, \mathrm{B}\right)=0 \\
\mathrm{~h}\left(\sigma_{\mathrm{ij}} \varepsilon_{\mathrm{ij}}, \mathrm{C}\right)=0
\end{gathered}
$$

where: $A, B, C$ are the specific parameters of the material. Each of the equations has different implications in the physical characterization of the failure, so it can be caused by tension, deformation or mechanical work.

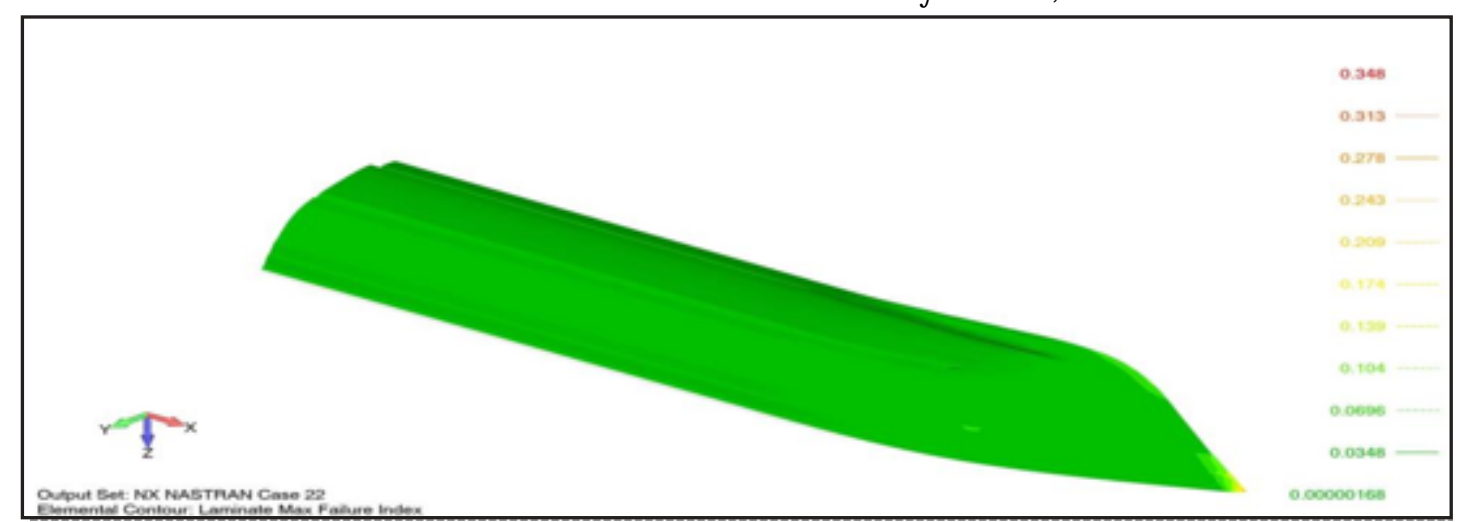

Fig. 8. Failure index for the initial structure of the craft subjected to impact on a wave crest at $10 \mathrm{~m} / \mathrm{s}$ 
For composite materials, a number of macromecanic and micromechanical failure criteria have been developed over time. From the macromecanic criteria we can list the maximum stress criteria, the maximum specific deformation criterion, the Hill criterion, the Hoffman criterion, the Tsai-Wu criterion, Hashin-Rotem criterion or the Puck criterion. Analyzing from a micro-mechanic point of view of the phases we can mention the Azzi-Tsai criterion, the Franklin criterion, Prager criterion and many others.

In the analysis of the structure performed in this paper, the macro-mechanical Hoffman criterion was used, due to the simplicity of use and integration in the FEA analysis program used. The equation of the criterion used for the flat stress state is:

$$
\begin{aligned}
\mathrm{F} & =\frac{\sigma_{1}^{2}}{\mathrm{X}_{1 \mathrm{t}} \mathrm{X}_{1 \mathrm{c}}}+\frac{\sigma_{2}^{2}}{\mathrm{X}_{2 \mathrm{c}} \mathrm{X}_{2 \mathrm{t}}}+\frac{\sigma_{12}^{2}}{\mathrm{~S}^{2}}-\frac{\sigma_{1} \sigma_{2}}{\mathrm{X}_{1 \mathrm{c}} \mathrm{X}_{1 \mathrm{c}}}+ \\
& +\left(\frac{1}{\mathrm{X}_{1 \mathrm{t}}}-\frac{1}{\mathrm{X}_{1 \mathrm{c}}}\right) \sigma_{1}+\left(\frac{1}{\mathrm{X}_{2 \mathrm{t}}}-\frac{1}{\mathrm{X}_{2 \mathrm{c}}}\right) \sigma_{2} .
\end{aligned}
$$

where $X_{i t}$ and $X_{i c}$ are the limit stress to elongation and compression in the direction $i$ of the lamina

The integrity of the lamina is provided for $\mathrm{F}<1$.

The failure criteria analisys for the initial monolithic classic GRP structure demonstrates that the maximum value recorded for the failure index is $F=0.348$, as it can be seen from the figure 8 .

The alternative structures, of which six are sandwich and three hybrid sandwich structures are presented in table 7 . The same load conditions, geometryand mesh refinement that were used to study the initial stratification

version were preserved.
In table 7, $E_{x}$ is the longitudinal elastic modulus on one direction and $\mathscr{E}_{x b}$ on a perpendicular direction to the first one.

Even presented in a simplified version, the comparative evaluation of the deformations, stress and masses of the nine proposals and the original is difficult to perform. In order to evaluate and hierarchize the structures, four adimensional indicators were established in order to characterize each structure in terms of mass $\left(I_{\mathrm{m}}\right)$, maximum stress $\left(I_{t}\right)$, maximum deformation $\left(I_{d}\right)$ and Hoffman failure index $(F)$ [1].

The mass index was calculated by reporting the mass of each alternative structure to the mass of the original structure. Thus, lighter structures get a subunit index and the heavier a superunit index. Similarly, the index of maximum stress will report the maximum stress recorded in the measured points for each alternate structure to the maximum stress of the original structure. All maximum stress values were recorded on the position of M4 transducer, being an area close to the middle of the length of the boat where the maximum value of bending momentum has been recorded, showing greatest interest. The maximum deformation index will compare the values of the deformations recorded at the same measuring point corresponding to $\mathrm{M} 4$, in a similar way as the maximum stress index and will refer them to the maximum deformation of the initial structure.

Each structure will ultimately be characterized by a global index Characteristic of the Laminate $(C L)$ that will have the formulation:

$$
C L=\sqrt{I_{m}^{2}+I_{t}^{2}+I_{d}^{2}+F^{2}}
$$

Table 7

\begin{tabular}{|c|c|c|c|c|c|c|c|}
\hline \multicolumn{2}{|c|}{ KEEL } & \multicolumn{2}{|c|}{ BOTTOM SIDE } & \multicolumn{2}{|c|}{ SIDEBOARD } & \multicolumn{2}{|c|}{ DECK } \\
\hline \multicolumn{8}{|c|}{ Material l (OC) } \\
\hline \multicolumn{8}{|c|}{ ORIGINAL + COREMAT } \\
\hline $3 \mathrm{x} \operatorname{CSM} 450$ & \multirow{6}{*}{$\begin{array}{c}\text { thickness } \\
11,3 \mathrm{~mm} \\
\mathrm{Ex}=6,88 \\
\mathrm{GPa} \\
\mathrm{Exb}=8,28 \\
\mathrm{GPa}\end{array}$} & $\begin{array}{l}3 \mathrm{XCSM} \\
450\end{array}$ & \multirow{6}{*}{$\begin{array}{c}\text { thickness } 10,25 \\
\quad \mathrm{~mm} \\
\mathrm{Ex}=6,62 \mathrm{GPa} \\
\mathrm{Exb}=8,47 \mathrm{GPa}\end{array}$} & $2 \mathrm{X} \operatorname{CSM} 450$ & \multirow{6}{*}{$\begin{array}{c}\text { thickness } 7,9 \mathrm{~mm} \\
\mathrm{Ex}=5,43 \mathrm{GPa} \\
\mathrm{Ex} b=7,60 \mathrm{GPa}\end{array}$} & $\begin{array}{l}2 \mathrm{XCSM} \\
450\end{array}$ & \multirow{6}{*}{$\begin{array}{c}\text { thickness } \\
7,9 \mathrm{~mm} \\
\mathrm{Ex}=5,43 \\
\mathrm{GPa} \\
\mathrm{Exb}=7,60 \\
\mathrm{GPa}\end{array}$} \\
\hline $1 \mathrm{X}$ WR 300 & & COREMAT & & COREMAAT & & COREMLAT & \\
\hline COREMAT & & $1 \mathrm{X}$ WR 300 & & $1 \mathrm{X} \operatorname{CSM} 450$ & & $\begin{array}{l}1 \mathrm{XCSM} \\
450\end{array}$ & \\
\hline $1 \mathrm{X} \operatorname{CSM} 450$ & & $\begin{array}{l}1 \mathrm{XCSM} \\
450\end{array}$ & & $1 \mathrm{X}$ WR 300 & & $1 \mathrm{XWR} 300$ & \\
\hline $1 \mathrm{X}$ WR 500 & & $1 \mathrm{XWR} 500$ & & $1 \mathrm{X} \operatorname{CSM} 450$ & & $\begin{array}{l}1 \mathrm{X} \text { CSM } \\
450\end{array}$ & \\
\hline $2 \mathrm{x} \operatorname{CSM} 450$ & & $\begin{array}{l}1 \mathrm{X} \text { CSM } \\
450\end{array}$ & & & & & \\
\hline \multicolumn{8}{|c|}{ Material 2 (OF) } \\
\hline \multicolumn{8}{|c|}{ ORIGINAL + FOAM } \\
\hline $3 \mathrm{X} \operatorname{CSM} 450$ & \multirow{6}{*}{$\begin{array}{c}\text { thickness } \\
18,3 \mathrm{~mm} \\
\mathrm{Ex}=4,08 \\
\mathrm{GPa} \\
\mathrm{Exb}=7,23 \\
\mathrm{Gpa}\end{array}$} & $\begin{array}{l}3 \mathrm{XCSM} \\
450\end{array}$ & \multirow{6}{*}{$\begin{array}{l}\text { thickness } 17,25 \\
\quad \mathrm{~mm} \\
\mathrm{Ex}=3,71 \mathrm{GPa} \\
\mathrm{Exb}=6,93 \mathrm{GPa}\end{array}$} & $2 \mathrm{X} \operatorname{CSM} 450$ & \multirow{6}{*}{$\begin{array}{c}\text { thickness } 14,9 \\
\operatorname{mm} \\
\mathrm{Ex}=2,67 \mathrm{GPa} \\
\mathrm{Exb}=5,55 \mathrm{GPa}\end{array}$} & $\begin{array}{l}2 \mathrm{X} \text { CSM } \\
450\end{array}$ & \multirow{6}{*}{$\begin{array}{c}\text { thickness } \\
14,9 \mathrm{~mm} \\
\mathrm{Ex}=2,67 \\
\mathrm{GPa} \\
\mathrm{Exb}=5,55 \\
\mathrm{GPa}\end{array}$} \\
\hline $1 \mathrm{X}$ WR 300 & & FOAM & & FOAM & & FOAM & \\
\hline FOAM & & $1 \mathrm{XWR} 300$ & & $1 \mathrm{X} \mathrm{CSM} 450$ & & $\begin{array}{l}1 \mathrm{XCSM} \\
450\end{array}$ & \\
\hline $1 \mathrm{X} \operatorname{CSM} 450$ & & $\begin{array}{l}1 \mathrm{X} \text { CSM } \\
450\end{array}$ & & $1 \mathrm{X}$ WR 300 & & $1 \mathrm{XWR} 300$ & \\
\hline $1 \mathrm{X}$ WR 500 & & $1 \mathrm{XWR} 500$ & & $1 \mathrm{X} \operatorname{CSM} 450$ & & $\begin{array}{l}1 \mathrm{XCSM} \\
450\end{array}$ & \\
\hline $2 \mathrm{x} \operatorname{CSM} 450$ & & $\begin{array}{l}1 \mathrm{X} \text { CSM } \\
450\end{array}$ & & & & & \\
\hline \multicolumn{8}{|c|}{ Material 3 (OCL) } \\
\hline \multicolumn{8}{|c|}{ ORIGINAL + COREMAT, LIGHT } \\
\hline $2 \mathrm{X} \operatorname{CSM} 450$ & \multirow{7}{*}{$\begin{array}{c}\text { thicloness } \\
10,25 \mathrm{~mm} \\
\mathrm{Ex}=6,80 \\
\mathrm{GPa} \\
\mathrm{Exb}=8,85 \\
\mathrm{GPa}\end{array}$} & $\begin{array}{l}1 \mathrm{X} \text { CSM } \\
450\end{array}$ & \multirow{7}{*}{$\begin{array}{l}\text { thickness } 9,35 \\
\quad \mathrm{~mm} \\
\mathrm{Ex}=6,71 \mathrm{GPa} \\
\mathrm{Exb}=8,92 \mathrm{GPa}\end{array}$} & $1 \mathrm{X} \operatorname{CSM} 450$ & \multirow{7}{*}{$\begin{array}{l}\text { thickness } 6,65 \\
\quad \mathrm{~mm} \\
\mathrm{Ex}=5,36 \mathrm{GPa} \\
\mathrm{Exb}=7,81 \mathrm{GPa}\end{array}$} & $1 \mathrm{X} \operatorname{CSM} 450$ & \multirow{7}{*}{$\begin{array}{c}\text { thiclones5 } \\
6,65 \mathrm{~mm} \\
\mathrm{Ex}=5,36 \\
\mathrm{GPa} \\
\mathrm{Exb}=7,81 \\
\mathrm{GPa}\end{array}$} \\
\hline $1 \mathrm{X}$ WR 300 & & $1 \mathrm{X}$ WR 300 & & $1 \mathrm{X}$ WR 300 & & $1 \mathrm{X}$ WR 300 & \\
\hline $1 \mathrm{X} \operatorname{CSM} 450$ & & $\begin{array}{l}1 \mathrm{X} \text { CSM } \\
450\end{array}$ & & COREMAT & & COREMAT & \\
\hline COREMAT & & COREMLAT & & $1 \mathrm{X}$ WR 300 & & $1 \mathrm{X}$ WR 300 & \\
\hline $1 \mathrm{X} \operatorname{CSM} 450$ & & $\begin{array}{l}1 \mathrm{XCSM} \\
450\end{array}$ & & & & & \\
\hline $1 \mathrm{X}$ WR 500 & & $1 \mathrm{X}$ WR 500 & & $1 \mathrm{X} \operatorname{CSM} 450$ & & $1 \mathrm{X} \operatorname{CSM} 450$ & \\
\hline $1 \mathrm{X} \operatorname{CSM} 450$ & & $\begin{array}{l}1 \mathrm{X} \text { CSM } \\
450\end{array}$ & & & & & \\
\hline
\end{tabular}

THE DESCRIPTION OF STRATIFICATION FOR ALTERNATIVE PROPOSALS AND MECHANICAL CHARACTERISTICS CALCULATED BY THE FEM ANALYSIS SOFTWARE [1] 


\begin{tabular}{|c|c|c|c|c|c|c|c|}
\hline \multirow{2}{*}{\multicolumn{8}{|c|}{$\begin{array}{l}\text { Material 4 (OFL) } \\
\text { ORIGINAL + FOAM, LIGHT }\end{array}$}} \\
\hline & & & \multirow{8}{*}{$\begin{array}{l}\text { thiclmess } 16,2 \\
\mathrm{~mm} \\
\mathrm{Ex}=3,60 \mathrm{GPa} \\
\mathrm{Exb}=6,99 \mathrm{GPa}\end{array}$} & & & & \\
\hline $1 \mathrm{X} \operatorname{CSM} 450$ & \multirow{7}{*}{$\begin{array}{c}\text { thickness } \\
17,25 \mathrm{~mm} \\
\mathrm{Ex}=3,70 \\
\mathrm{GPa} \\
\mathrm{Exb}=6,96 \\
\mathrm{GPa}\end{array}$} & $\begin{array}{l}3 \mathrm{X} \text { CSM } \\
450\end{array}$ & & $2 \mathrm{X} \operatorname{CSM} 450$ & \multirow{7}{*}{$\begin{array}{c}\text { thickness } 13,85 \\
\text { mm } \\
\mathrm{Ex}=2,35 \mathrm{GPa} \\
\mathrm{Exb}=5,13 \mathrm{GPa}\end{array}$} & $\begin{array}{l}2 \mathrm{XCSM} \\
450\end{array}$ & \multirow{7}{*}{$\begin{array}{c}\text { thickness } \\
13,85 \mathrm{~mm} \\
\mathrm{Ex}=2,35 \\
\mathrm{GPa} \\
\mathrm{Exb}=5,13 \\
\mathrm{GPa}\end{array}$} \\
\hline $1 \mathrm{X}$ WR 300 & & FOAM & & FOAM & & FOAM & \\
\hline $1 \mathrm{X} \operatorname{CSM} 450$ & & $1 \mathrm{XWR} 300$ & & $1 \mathrm{X} \operatorname{CSM} 450$ & & $\begin{array}{l}1 \mathrm{X} \text { CSM } \\
450\end{array}$ & \\
\hline FOAM & & $\begin{array}{l}1 \mathrm{X} \text { CSM } \\
450\end{array}$ & & $1 \mathrm{X}$ WR 300 & & $1 \mathrm{X}$ WR 300 & \\
\hline $2 \mathrm{X} \operatorname{CSM} 450$ & & $1 \mathrm{X}$ WR 500 & & $1 \mathrm{X} \operatorname{CSM} 450$ & & $\begin{array}{l}1 \mathrm{X} \text { CSM } \\
450\end{array}$ & \\
\hline $1 \mathrm{X}$ WR 500 & & $\begin{array}{l}1 \mathrm{XCSM} \\
450\end{array}$ & & & & & \\
\hline $1 \mathrm{X} \mathrm{CSM} 450$ & & & & & & & \\
\hline \multicolumn{8}{|l|}{ Material 5 (C) } \\
\hline \multicolumn{8}{|l|}{ COREMAT } \\
\hline $2 \mathrm{X} \operatorname{CSM} 450$ & \multirow{5}{*}{$\begin{array}{c}\text { thickness } \\
8,35 \mathrm{~mm} \\
\mathrm{Ex}=6,0 \\
\mathrm{GPa} \\
\mathrm{Exb}=8,0 \\
\mathrm{GPa}\end{array}$} & $\begin{array}{l}2 \mathrm{X} \text { CSM } \\
450 \\
\end{array}$ & \multirow{5}{*}{$\begin{array}{c}\text { thickness } 8,05 \\
\text { mm } \\
\mathrm{Ex}=5,5 \mathrm{GPa} \\
\mathrm{Exb}=7,62 \mathrm{GPa}\end{array}$} & $2 \mathrm{X} \operatorname{CSM} 450$ & \multirow{5}{*}{$\begin{array}{c}\text { thickness } 7,2 \mathrm{~mm} \\
\mathrm{Ex}=5,0 \mathrm{GPa} \\
\mathrm{Exb}=7,31 \mathrm{GPa}\end{array}$} & $\begin{array}{l}2 \mathrm{X} \text { CSM } \\
450\end{array}$ & \multirow{5}{*}{$\begin{array}{c}\text { thickness } \\
6,15 \mathrm{~mm} \\
\mathrm{Ex}=4,39 \\
\mathrm{GPa} \\
\mathrm{Exb}=6,53 \\
\mathrm{GPa}\end{array}$} \\
\hline COREMAT & & COREMAT & & COREMAT & & COREMAT & \\
\hline $1 \mathrm{X} \operatorname{CSM} 450$ & & $\begin{array}{l}1 \mathrm{XCSM} \\
450\end{array}$ & & $1 \mathrm{X} \operatorname{CSM} 450$ & & $\begin{array}{l}1 \mathrm{X} \text { CSM } \\
450\end{array}$ & \\
\hline $1 \mathrm{X}$ WR 500 & & $1 \mathrm{X}$ WR 500 & & & & & \\
\hline $1 \mathrm{X} \operatorname{CSM} 450$ & & $\begin{array}{l}1 \mathrm{X} \text { CSM } \\
450\end{array}$ & & & & & \\
\hline \multicolumn{8}{|l|}{ Material 6(F) } \\
\hline \multicolumn{8}{|l|}{ FOAM } \\
\hline $2 \mathrm{X} \mathrm{CSM} 450$ & \multirow{5}{*}{$\begin{array}{c}\text { thickness } \\
15,35 \mathrm{~mm} \\
\mathrm{Ex}=2,98 \\
\mathrm{GPa} \\
\mathrm{Exb}=5,95 \\
\mathrm{GPa}\end{array}$} & $\begin{array}{l}2 \mathrm{XCSM} \\
450\end{array}$ & \multirow{5}{*}{$\begin{array}{c}\text { thickness } 15,05 \\
\text { mm } \\
\mathrm{Ex}=2,73 \mathrm{GPa} \\
\mathrm{Exb}=5,60 \mathrm{GPa}\end{array}$} & $2 \mathrm{X} \mathrm{CSM} 450$ & \multirow{5}{*}{$\begin{array}{c}\text { thickness } 14,20 \\
\mathrm{~mm} \\
\mathrm{Ex}=2,35 \mathrm{GPa} \\
\mathrm{Ex} b=5,10 \mathrm{GPa}\end{array}$} & $\begin{array}{l}2 \mathrm{X} \text { CSM } \\
450\end{array}$ & \multirow{5}{*}{$\begin{array}{c}\text { thickness } \\
13,15 \mathrm{~mm} \\
\mathrm{Ex}=1,76 \\
\mathrm{GPa} \\
\mathrm{Exb}=3,94 \\
\mathrm{GPa}\end{array}$} \\
\hline FOAM & & FOAM & & FOAM & & FOAM & \\
\hline $1 \mathrm{X} \operatorname{CSM} 450$ & & $\begin{array}{l}1 \mathrm{X} \text { CSM } \\
450\end{array}$ & & $1 \mathrm{X} \operatorname{CSM} 450$ & & $\begin{array}{l}1 \mathrm{X} \text { CSM } \\
450\end{array}$ & \\
\hline $1 \mathrm{X}$ WR 500 & & $1 \mathrm{X}$ WR 300 & & & & & \\
\hline $1 \mathrm{X} \operatorname{CSM} 450$ & & $\begin{array}{l}1 \mathrm{X} \text { CSM } \\
450\end{array}$ & & & & & \\
\hline \multicolumn{8}{|c|}{ Material 7 (Hl) } \\
\hline \multicolumn{8}{|l|}{ HYBRID 1} \\
\hline $2 \mathrm{X}$ CSM 450 & & $\begin{array}{l}2 \mathrm{XCSM} \\
450\end{array}$ & & $2 \mathrm{X}$ CSM 450 & & $1 \mathrm{X}$ CSM 450 & \\
\hline COREMAT & & COREMLAT & & COREMAT & & COREMAT & \\
\hline $1 \mathrm{X} \operatorname{CSM} 450$ & thicloness & $\begin{array}{l}1 \mathrm{X} \text { CSM } \\
450\end{array}$ & thickness 19,1 & $1 \mathrm{X} \operatorname{CSM} 450$ & thickness 17,2 & $1 \mathrm{X} \operatorname{CSM} 450$ & thickness \\
\hline FOAM & $\begin{array}{c}\mathrm{Ex}=3,09 \\
\mathrm{GP}\end{array}$ & SPUMÁ & $\stackrel{m m}{\mathrm{~mm}=281 \mathrm{GPz}}$ & FOAM & $\stackrel{\mathrm{mm}}{\mathrm{Ex}=1.80 \mathrm{GPz}}$ & FOAM & $\begin{array}{c}E x=1,65 \\
\mathrm{EP}\end{array}$ \\
\hline $1 \mathrm{X} \mathrm{CSM} 450$ & $\begin{array}{c}\mathrm{GPa} \\
\mathrm{Exb}=5,80 \\
\mathrm{GPa}\end{array}$ & $\begin{array}{l}1 \mathrm{X} \mathrm{CSM} \\
450\end{array}$ & $\begin{array}{l}\mathrm{Ex}=2,81 \mathrm{GPa} \\
\mathrm{Exb}=5,36 \mathrm{GPa}\end{array}$ & $1 \mathrm{X} \operatorname{CSM} 450$ & $\begin{array}{l}\mathrm{Ex}=1,80 \mathrm{GPa} \\
\mathrm{Exb}=3,27 \mathrm{GPa}\end{array}$ & $1 \mathrm{X} \operatorname{CSM} 450$ & $\begin{array}{c}\mathrm{GPa} \\
\mathrm{Exb}=3,06\end{array}$ \\
\hline $1 \mathrm{X}$ WR 500 & & IX WR 300 & & & & & \\
\hline $1 \mathrm{X} \mathrm{CSM} 450$ & & $\begin{array}{l}1 \mathrm{XCSM} \\
450\end{array}$ & & & & & \\
\hline Material 8 (H) & & & & & & & \\
\hline HYBRID 2 & & & & & & & \\
\hline $1 \mathrm{X}$ CSM 450 & & $\begin{array}{l}1 \mathrm{X} \text { CSM } \\
450\end{array}$ & & $2 \mathrm{X} \operatorname{CSM} 450$ & & $\begin{array}{l}1 \mathrm{X} \text { CSM } \\
450\end{array}$ & \\
\hline $1 \mathrm{XWR} 500$ & & $1 \mathrm{X}$ WR 500 & & FOAM & & COREMAT & \\
\hline $1 \mathrm{X} \mathrm{CSM} 450$ & thickness & COREMAT & & $1 \mathrm{X} \operatorname{CSM} 450$ & & $\begin{array}{l}1 \mathrm{X} \text { CSM } \\
450\end{array}$ & thickness \\
\hline FOAM & $\begin{array}{l}20,7 \mathrm{~mm} \\
\mathrm{Ex}=3,83\end{array}$ & $\begin{array}{l}1 \mathrm{XCSM} \\
450\end{array}$ & thickness 19,65 & COREMAT & $\begin{array}{l}\text { thickness } 18,35 \\
\text { mm }\end{array}$ & FOAM & $\begin{array}{l}17,3 \mathrm{~mm} \\
\mathrm{Ex}=2,49\end{array}$ \\
\hline $1 \mathrm{X} \operatorname{CSM} 450$ & $\begin{array}{c}\mathrm{GPa} \\
\mathrm{Exb}=721\end{array}$ & FOAM & $\begin{array}{c}\mathrm{Ex}=3,64 \mathrm{GPa} \\
\mathrm{Exb}=698 \mathrm{GPa}\end{array}$ & $1 \mathrm{XWR} 500$ & $\begin{array}{c}\mathrm{Ex}=2,67 \mathrm{GPa} \\
\mathrm{Exb}=5,1 \mathrm{GPa}\end{array}$ & $1 \mathrm{X}$ WR 500 & $\begin{array}{c}\mathrm{GPa} \\
\text { Exb=4 } 80\end{array}$ \\
\hline COREMAT & $\begin{array}{l}\mathrm{Exb}=l, 21 \\
\mathrm{GPa}\end{array}$ & $\begin{array}{l}1 \mathrm{X} \text { CSM } \\
450\end{array}$ & & $1 \mathrm{X}$ CSM 450 & & $\begin{array}{l}1 \mathrm{X} \operatorname{CSM} \\
450\end{array}$ & $\begin{array}{c}\mathrm{Exb}=4,80 \\
\mathrm{GPa}\end{array}$ \\
\hline $1 \mathrm{X} \operatorname{CSM} 450$ & & $1 \mathrm{X}$ WR 500 & & & & & \\
\hline $1 \mathrm{XWR} 500$ & & $1 \mathrm{XCSM}$ & & & & & \\
\hline $1 \mathrm{X} \operatorname{CSM} 450$ & & 450 & & & & & \\
\hline Material $9\left(\mathrm{H}^{2}\right.$ & & & & & & & \\
\hline HYBRID 3 & & & & & & & \\
\hline $1 \mathrm{X} \mathrm{CSM} 450$ & & $\begin{array}{l}1 \mathrm{X} \text { CSM } \\
450\end{array}$ & & $1 \mathrm{X} \operatorname{CSM} 450$ & & $1 \mathrm{X} \operatorname{CSM} 450$ & \\
\hline $1 \mathrm{XWR} 500$ & thickness & $1 \mathrm{XWR} 500$ & & $1 \mathrm{X}$ WR 500 & & COREMAT & thickness \\
\hline FOAM & $18,61 \mathrm{~mm}$ & COREMAT & thickness 18,6 & COREMAT & thickness 17,3 & $1 \mathrm{X}$ CSM 450 & $17,1 \mathrm{~mm}$ \\
\hline $1 \mathrm{X} \mathrm{CSM} 450$ & $\begin{array}{c}\mathrm{Ex}=3,35 \\
\mathrm{GPa}\end{array}$ & $\begin{array}{l}1 \mathrm{XCSM} \\
450\end{array}$ & $\begin{array}{c}\mathrm{mm} \\
\mathrm{Ex}=3,38 \mathrm{GPa}\end{array}$ & $1 \mathrm{X} \operatorname{CSM} 450$ & $\begin{array}{c}\mathrm{mm} \\
\mathrm{Ex}=2,48 \mathrm{GPa}\end{array}$ & FOAM & $\begin{array}{c}\mathrm{Ex}=2,40 \\
\mathrm{GPa}\end{array}$ \\
\hline COREMAT & $\mathrm{Exb}=6,44$ & FOAM & $\mathrm{Exb}=6,53 \mathrm{GPa}$ & FOAM & $\mathrm{Ex} b=4,81 \mathrm{GPa}$ & $1 \mathrm{XWR} 500$ & $\mathrm{Exb}=4,74$ \\
\hline $1 \mathrm{X}$ WR 500 & $\mathrm{GPa}$ & $1 \mathrm{XWR} 500$ & & $1 \mathrm{XCSM} 450$ & & $1 \mathrm{X} \operatorname{CSM} 450$ & \\
\hline $1 \mathrm{X} \operatorname{CSM} 450$ & & $\begin{array}{l}1 \mathrm{XCSM} \\
450\end{array}$ & & & & & \\
\hline
\end{tabular}

The purpose of calculating the indices specific for each characteristic and global index of the structures is to establish a hierarchy, in ascending order of the global index. Thus, each of the sub-unit specific indices of each category creates an advantage of the analyzed structure, and the supraunits a disadvantage. The lower the index of a structure, the better it ranks among the competitors.
The values of the indices calculated according to the above-mentioned principle, which are ordered in ascending order, are presented in table 8 . The structural variant $\mathrm{C}$ was included in the evaluation, although it has a failure index that disqualifies it. 
Table 8

RANKING OF STRUCTURES STUDIED IN ACCORDING WITH THE CL INDEX

\begin{tabular}{|c|c|c|c|c|c|c|c|c|c|}
\hline Rank & Variant & $\begin{array}{c}\text { Mass } \\
{[\mathrm{kg}]}\end{array}$ & $I_{m}$ & $\begin{array}{c}\text { Max stress } \\
\text { [MPa] }\end{array}$ & $\mathrm{I}_{\mathrm{t}}$ & $\begin{array}{c}\text { Max Def. } \\
\text { [mm] }\end{array}$ & $\mathrm{Id}_{\mathrm{d}}$ & $\mathbf{F}$ & $C L$ \\
\hline 2 & $\mathrm{OF}$ & 350,40 & 1,040 & 9,1632 & 0,779 & 30,09 & 0,628 & 0,211 & 1,458 \\
\hline 4 & $\mathrm{H} 3$ & 326,84 & 0,970 & 9,6048 & 0,816 & 40,74 & 0,850 & 0,436 & 1,587 \\
\hline 5 & $\mathrm{OC}$ & 370,72 & 1,100 & 9,8183 & 0,835 & 36,21 & 0,756 & 0,202 & 1,587 \\
\hline 6 & $\mathrm{OCL}$ & 308,96 & 0,917 & 11.6896 & 0.994 & 45,84 & 0,957 & 0,317 & 1.686 \\
\hline 9 & $\mathrm{~F}$ & 260,98 & 0,774 & 14,2363 & 1,210 & 48,30 & 1,008 & 0,978 & 2,009 \\
\hline 10 & $C$ & 283,90 & 0,842 & 15,5307 & 1,320 & 60,61 & 1,265 & 1,128 & 2,308 \\
\hline
\end{tabular}

\section{Conclusions}

The scantling carried out in accordance with the rules of the classification companies considers the material as isotropic and even if this is not completely true, the calculations using this formulation overpredict the stresses, resulting in a safer structure.

Looking at the results we can see that the $C L$ index variations for the proposed structures versus the initial version (position 8, GRP) vary within the limit of approximately $23 \%$. By analyzing the structures in the ascending order of the global index, we can formulate the following conclusions [1]:

- the Coremat (C) structure has the largest characteristic index of the laminate, but has the second lightest mass of all proposed structures. With minor modifications, this option could be considered as a potential alternative structure candidate;

- the Foam Structure $(F)$ is the lightest structure of all proposals analyzed, but the other indices are bigger than the ones of the original structure. The failure index also has values close to the threshold, which draws attention to the fact that this structural option also requires improvements;

- the firsthybrid proposal, $\mathrm{H} 1$ shows minor improvements in mass and stress, but is more elastic and is therefore ranked $7^{\text {th }}$;

- the Original + Coremat Light $(O C L)$ variant is the first variant that provides subunit specific indices for the all of the pursued categories of enhancement, but without significant improvement;

- the Hybrid 3 and Original + Coremat (OC) structures have the same global index calculated, but the OC variant has a larger mass than the original structure, while the $\mathrm{H} 3$ version brings improvements for all individual indicators;

- the proposal Original + Foam Light (OFL)is the bestranked alternative version that records a smaller mass than the original proposal, with a significant $12.9 \%$ reduction;

- the Original + Foam (OS) proposal brings substantial improvements in the stresses and displacements recorded and shows the lowest failure index. The only disadvantage it poses is that the structure is heavier by $4 \%$;

- the best ranked version of all is the Hybrid $2(\mathrm{H} 2)$ proposal, which shows the lowest displacements (by $44.8 \%$ ) and the lowest stress (by 29.7\%) compared to the original variant, having the only the notable disadvantage of a larger mass (by $8.6 \%$ ).
After this analysis, it can be said that the GRP structures used in recreational crafts can be improved by alternative proposals with sandwich structures, and these improvements can be evaluated at the early design stages in a systematic manner using appropriate numerical tools. The flexibility of combining composite materials and permanent innovation in composite's constituent raw materials allows designers to choose new combinations whenever a new product is being developed or an existing product is being improved.

\section{References}

1. CARAMATESCU, A., Analiza comparativa a structurilor clasice si hibride folosite la ambarcatiuni din GRP, metode de usurare a acestora si imbunatatirea rezistentei la impactul cu valurile, Teza de Doctorat, 2018

2.*** DNV-GL I Ship Technology : Rules: Yachts and Boats up to $24 \mathrm{~m}$ 3. STRONG, A.B., Fundamentals of composites manufacturing: materials, methods and applications, second edition, 2007

4.*** http://www.rompolimer.ro/fise_tehnice/_TDS_ENYDYNE_H_ 68372_TAE.RO.pdf

5. *** $\bar{h}$ ttp://www.owenscorning.com.cn/Form_Up/Images/24969-A.pdf 6. CARAMATESCU, A., MOCANU, C. I., PACURARU, F. D., JAGITE, G., Estimation of planing forces in numerical and full scale experiment, International Maritime Association of the Mediteranean, Lisbon, 2017 7. HADÍR, A., JIGA, G., BAYER, M., The configuration optimization of a glass fibre reinforced laminate, Mat. Plast., 42, no. 2, 2005, p. 100-105 8. NASTASESCU, V., MARZAVAN, S., Upon Impact Numerical Modeling of Foam Materials, Mat. Plast., 54, no. 2, 2017, p. 195-202

9. PETRESCU, H.A., HADAR, A., Influence of the Loading Position on a Honeycomb Sandwich Using Nonlinear Analysis, Mat. Plast., 48, no. 2, 2011, p. 202-207

10. PETRESCU, H.-A., HADAR, A., PASTRAMA, ST.D., Experimental Program for Impact Tests on a Honeycomb Core Composite Material, Proceedings of The Romanian Academy, Series A - Mathematics Physics Technical Sciences Information Science, 18 (2), 2017, pp. 150-157

11.***http://lantor.com/wp-content/uploads/2016/07/20160196_LANT_ DATASHEET COREMAT XM_web.pdf

12.***http://www.cristex.co.uk/products/woven-fabrics/pvc

Manuscript received: 14.12 .2018 